\title{
Solar Thermochemical Hydrogen Production in the USA
}

\author{
Christoph Falter *, + iD and Andreas Sizmann \\ Bauhaus Luftfahrt e.V., Willy-Messerschmitt-Str. 1, 82024 Taufkirchen, Germany; \\ andreas.sizmann@bauhaus-luftfahrt.net \\ * Correspondence: falter@mit.edu \\ † Current address: Laboratory for Aviation and the Environment, Department of Aeronautics and Astronautics, \\ Massachusetts Institute of Technology, Massachusetts Avenue 77, Cambridge, MA 02139, USA.
}

check for

updates

Citation: Falter, C.; Sizmann, A. Solar Thermochemical Hydrogen Production in the USA. Sustainability 2021, 13, 7804. https://doi.org/ $10.3390 /$ su13147804

Academic Editors: Antonio Valente and Diego Iribarren

Received: 1 June 2021

Accepted: 8 July 2021

Published: 13 July 2021

Publisher's Note: MDPI stays neutral with regard to jurisdictional claims in published maps and institutional affiliations.

Copyright: (c) 2021 by the authors. Licensee MDPI, Basel, Switzerland. This article is an open access article distributed under the terms and conditions of the Creative Commons Attribution (CC BY) license (https:/ / creativecommons.org/licenses/by/ $4.0 /)$.

\begin{abstract}
Hydrogen produced from renewable energy has the potential to decarbonize parts of the transport sector and many other industries. For a sustainable replacement of fossil energy carriers, both the environmental and economic performance of its production are important. Here, the solar thermochemical hydrogen pathway is characterized with a techno-economic and life-cycle analysis. Assuming a further increase of conversion efficiency and a reduction of investment costs, it is found that hydrogen can be produced in the United States of America at costs of 2.1-3.2 EUR/ kg (2.4-3.6 USD/ kg) at specific greenhouse gas emissions of $1.4 \mathrm{~kg} \mathrm{CO} 2-\mathrm{eq} / \mathrm{kg}$. A geographical potential analysis shows that a maximum of $8.4 \times 10^{11} \mathrm{~kg}$ per year can be produced, which corresponds to about twelve times the current global and about 80 times the current US hydrogen production. The best locations are found in the Southwest of the US, which have a high solar irradiation and short distances to the sea, which is beneficial for access to desalinated water. Unlike for petrochemical products, the transport of hydrogen could potentially present an obstacle in terms of cost and emissions under unfavorable circumstances. Given a large-scale deployment, low-cost transport seems, however, feasible.
\end{abstract}

Keywords: hydrogen; solar thermochemistry; fuel; TEA; LCA; geographical potential

\section{Introduction}

Hydrogen is an energy carrier that has a wide range of applications, e.g., in industry, residential heating, energy storage, and transportation. Its widespread economical production from renewable energy could help to decarbonize the economy and thus to contain the risk of progressing climate change. By replacing carbon-based reducing agents in chemical processes, natural gas and oil in residential heating, and fossil fuels in the transportation sector, the emissions of carbon dioxide as a greenhouse gas (GHG) can be significantly reduced. The European strategy to contain global warming to well below two Kelvin [1] therefore comprises the use of hydrogen in different sectors [2]. Japan and Germany, among other countries, have announced large investments into a hydrogen infrastructure [3,4].

Today, most of the hydrogen used is produced by the reforming of natural gas and coal [5], which is intrinsically tied to the eventual emission of GHGs. To reach the climate goals, a pathway has to be developed for the production of renewable hydrogen. Among the suggested options are water electrolysis, using renewable electricity, or the dissociation of biomass [6]. Electrolysis especially appears to be a viable option given the foreseeable large additions of renewable electricity generation capacity and the maturation of the involved processes. However, from a thermodynamic point of view, the solar thermochemical pathway is interesting because it has the potential for very high energy conversion efficiencies [7,8], which may allow low production costs in the future. This pathway is therefore analyzed here. Concentrated solar energy drives a two-step thermochemical cycle based on, e.g., cerium oxide to split water into hydrogen and oxygen. The hydrogen is then captured and stored on the site of the production plant before being transported to the final customer. 
The costs of solar hydrogen production using water electrolysis with photovoltaic electricity (PV-E) has been analyzed in [9-15]. The cost estimates vary over a large range, which is due in part to the date of the estimate and the large price reductions of PV electricity since. Emissions of GHGs from water electrolysis are discussed, i.a., in [16-19] and from hydrogen transport in [17,19-21]. Regarding the cost of hydrogen produced via solar thermochemical cycles, not many assessments have been performed. In [22], a cost range of 3.5-12.8€/ kg was estimated, while in [23], electrolysis with PV electricity was compared to the solar thermochemical pathway. In a sensitivity assessment, it was claimed that different learning rates and policy supports are investigated, and it was found that the costs of the solar thermochemical pathway drop more quickly than those of electrolysis [23]. Nevertheless, due to the comparably low maturity level of solar thermochemical hydrogen production and the rapid development of cost reductions of PV, this result should be reevaluated over time with continuously updated data. The solar thermochemical pathway for the production of jet fuel has been assessed with respect to production costs and environmental performance in [24], and recently while further including a social life cycle analysis [25]. The geographical potential of the same pathway was assessed in [26] for most of the sunny regions of the earth, identifying production potentials for jet fuel production that exceed the global demand by more than an order of magnitude.

In this paper, solar thermochemical hydrogen production is analyzed from a technoeconomic, an ecological, and a geographical point of view, where the United States of America are taken as the region of interest due to their attractive solar irradiation in the Southwest and large available areas. To this end, the production costs of a baseline case plant with a capacity of 100 tons per day and the emissions of greenhouse gases (GHGs) are estimated. For the baseline case, a location with a direct normal irradiation of $2700 \mathrm{kWh} /\left(\mathrm{m}^{2} \mathrm{y}\right)$ and with a distance of $250 \mathrm{~km}$ to the sea is chosen, which can be found, e.g., northeast of Los Angeles. In a geographical analysis, available areas are identified through the exclusion of unsuitable ones, following a list of sustainability criteria. With the information provided through this analysis, it is then possible to determine the possible GHG reductions from solar thermochemical hydrogen according to its production potential, costs, and specific GHG emissions.

\section{The Solar Thermochemical Pathway}

Fresh water is provided to the plant through seawater desalination at the seaside and subsequent pipeline transport to the plant location. The water is then split into hydrogen and oxygen via a two-step solar thermochemical redox cycle at temperatures of $1000-1900 \mathrm{~K}$ driven by concentrated solar radiation. The concentration of solar energy can be performed either by a field of heliostats that reflect onto a common target on top of a tower or through an array of dishes. For the latter, each dish has its own reactor, which has implications for the maximum reactor size and thus also for the plant layout, which requires a completely different gas distribution system than a centralized tower system. In this paper, only the tower system is discussed, due to more data being available. In the thermochemical reactors, a metal oxide reactant is cyclically heated to the upper process temperature, where at reduced oxygen partial pressure, the reactant releases a part of its oxygen content. At reduced temperature, water is injected and subsequently split into hydrogen and oxygen, whereas the latter is re-incorporated into the lattice of the reactant. Oxygen and hydrogen are produced in different process steps and are therefore separated, inherently preventing dangerous operating conditions. The hydrogen is captured, stored at an intermediate pressure of 16 bar on site, and can then be transported to the final customer. Not included in the costs in this analysis is the transportation cost of hydrogen. Depending on the location of the final customer, transport via pipeline (in a pressurized gaseous state) or via truck (either gaseous, liquefied or via other storage options such as liquid organic hydrogen carriers or metal organic frameworks) can be established. At large production volumes and longer distances, gaseous truck transport incurs high transport costs. 
Most of the process steps have already been commercially established, i.e., the desalination of seawater, the pipeline transport of water and (to a lesser degree) hydrogen, the concentration of solar energy in concentrated solar power (CSP) plants, and the storage and distribution of hydrogen. The main innovation potential in this production pathway is therefore with the thermochemical splitting of water into hydrogen and oxygen. Solar thermochemistry has been an active field of research for several decades. In recent years, a significant increase of experimentally demonstrated energy conversion efficiencies has been achieved. In 2010, an experiment with ceria bricks at the solar research facility of the Paul Scherrer Institute in Switzerland delivered an efficiency of $0.8 \%$ [27]. In the following years, the material structure of ceria was enhanced to a reticulated porous ceramic with improved heat transfer, which enabled efficiencies of $1.73 \%$ [28]. The introduction of vacuum pumping enabled another step up in efficiencies to more than 5.25\% [29]. These efficiencies were demonstrated with reactants made of pure cerium oxide, while the theoretical efficiency potential exceeded 50\% [8]. The establishment of an economically promising production pathway for combined water and $\mathrm{CO}_{2}$ splitting is expected to require efficiencies approaching $20 \%[24,25,30]$, and is therefore well within the thermodynamic limits of the process. With respect to economic viability, solar thermochemical $\mathrm{H}_{2}$ can be delivered without the penalty of $\mathrm{CO}_{2}$ capture and fuel synthesis, but with the addition of transportation, storage, and liquefaction. Further process enhancements are expected from material development (morphological structures [31] and redox potential [32]) and the recuperation of thermal energy of the cyclic heating and cooling of the reactant [33]. Heat recuperation is especially desirable for non-volatile redox materials that show relatively small nonstoichiometries of oxygen and which thus require a large amount of thermal energy input per mol of produced hydrogen. Apart from cerium oxide, other materials have been researched that promise higher specific productivities and lower specific energy inputs, such as doped cerium oxide [8,34] and perovskites [35-39].

A baseline case of a solar thermochemical plant is defined with a production capacity of 100 tons per day of hydrogen. The energy and mass balance per kilogram of hydrogen is shown in Figure 1. A location with a direct normal irradiation of $2700 \mathrm{kWh} /\left(\mathrm{m}^{2} \mathrm{y}\right)$ at a distance of $250 \mathrm{~km}$ to the sea is chosen. The produced oxygen is assumed to be vented to the atmosphere; while having an economic value, e.g., for medical applications, the implementation potential depends on the proximity to the market and the cost for storage and transport. If the production plant is close to a customer, the oxygen could be valorized. However, due to the most attractive locations being rather remote, the baseline case assumes venting of the oxygen. The freshwater requirements of the plant of $19.4 \mathrm{~L} / \mathrm{kg}$ $\mathrm{H}_{2}\left(1.94 \times 10^{6} \mathrm{~L} / \mathrm{d}\right)$ are covered by seawater desalination and pipeline transport to the plant location. The energy demand of seawater desalination is $3 \mathrm{kWh} / \mathrm{m}^{3}[40,41]$, and the energy demand for the transport of the water to the plant site is $0.1 \mathrm{kWh} / \mathrm{kg} \mathrm{H}_{2}$. As the seawater desalination plant is located at the seaside, the required electricity to obtain fresh water and to transport it to the plant location via pipeline is assumed to be taken from the grid. The water demand is comprised of $9 \mathrm{~L} / \mathrm{kg} \mathrm{H}_{2}$ for thermochemical conversion (assuming ideal recovery of unconverted water during oxidation), $9.8 \mathrm{~L} / \mathrm{kg} \mathrm{H}_{2}$ for mirror cleaning [42] (assuming no recycling), and $0.6 \mathrm{~L} / \mathrm{kg} \mathrm{H}_{2}$ for CSP electricity [42]. Solar energy is concentrated to produce heat and electricity on site to run the process. The plant requires mostly thermal energy $\left(1630.1 \mathrm{MJ} / \mathrm{kg} \mathrm{H}_{2}\right)$, which is provided by concentrated solar energy from a heliostat field that reflects onto a tower. The mirror area of the heliostat field is 6.2 million $\mathrm{m}^{2}$ and the optical efficiency of the field is $51.6 \%$ [43]. Electrical energy requirements for hydrogen storage $\left(5.6 \mathrm{MJ} / \mathrm{kg} \mathrm{H}_{2}\right)$ are met through an on-site solar plant. Electricity may be required for $24 \mathrm{~h}$ in the future, considering plant layouts with $24 \mathrm{~h}$ operation [33]. Solar electricity is assumed to have a unit cost of $0.04 \mathrm{EUR} / \mathrm{kWh}_{\mathrm{el}}$, which is higher than the costs of new PV plants in favorable locations [44] and lower than the costs of CSP plants [45]. Considering that such a thermochemical plant could be built in 10-15 years, the assumption of $0.04 \mathrm{EUR} / \mathrm{kWh}_{\mathrm{el}}$ represents a realistic estimate for a hybrid $\mathrm{PV} / \mathrm{CSP}$ plant in the future. All of the costs are included in the unit cost of electricity. 


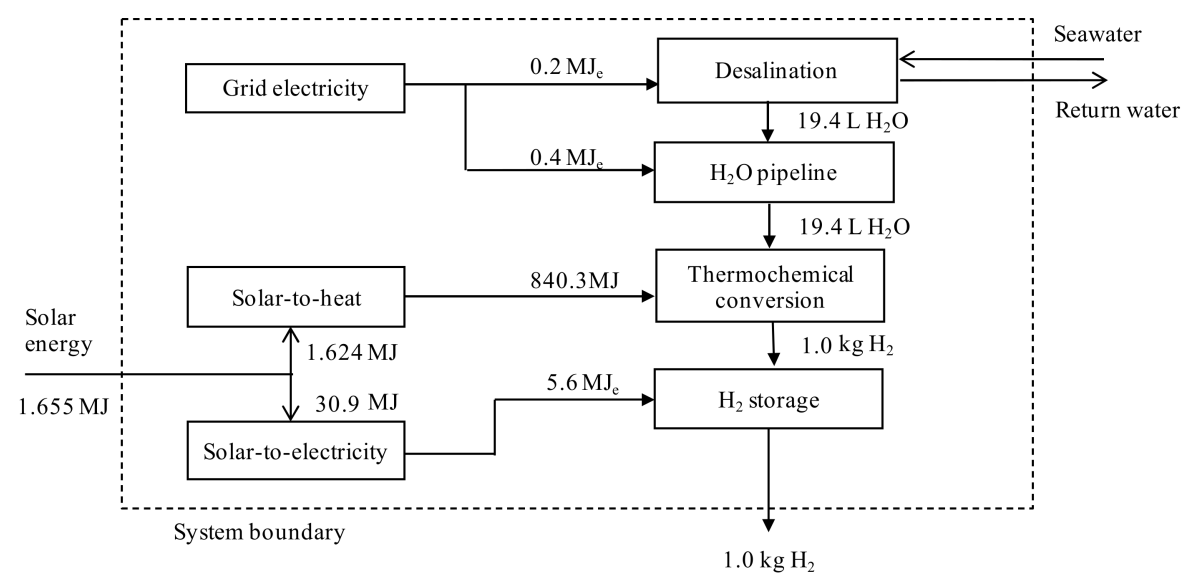

Figure 1. Energy and mass balance of the baseline case plant for solar thermochemical hydrogen production. The distance between seawater desalination and the thermochemical plant is $250 \mathrm{~km}$. Transport of the hydrogen to the final customer is not yet included.

By far the largest energy demand occurs for the thermochemical splitting of water, where the energy conversion efficiency is $18.4 \%$, excluding the energy required for vacuum pumping (14.3\% including vacuum pumping). A dedicated Matlab model is used to calculate the reactor efficiency for water splitting, which is based on a model in [25]. A reduced oxygen partial pressure during reduction is required for enhanced reaction rates. The pressure is chosen to minimize the levelized costs of hydrogen and is found as a trade-off between enhanced hydrogen productivity and increased energy demand towards lower pressures. The establishment of the reduction pressure of $1200 \mathrm{~Pa}$ is achieved by jet vacuum pumps that require the input of $188 \mathrm{MJ} / \mathrm{kg} \mathrm{H}_{2}$. Hydrogen is then stored at an intermediate pressure of 16 bar on site to enable short-term buffer storage for further transport to the place of its final use. The energy required for pressurizing hydrogen to the storage pressure is calculated assuming a polytropic compression from 1 to 16 bar with a polytropic exponent of 1.4 .

\section{Methodology}

\subsection{Techno-Economic Assessment}

The techno-economic assessment derives the production costs of solar thermochemical hydrogen using the levelized costs of energy [46], which sum all costs over the lifetime of the plant while taking into account the time value of money. From the total life cycle costs (TLCC), an annualized value is derived using the annuity method, and finally the costs per kilogram of hydrogen are found by referring to the annual production volume. The TLCC are calculated with Equation (1) [46]. The Equation calculates the amount of revenue that is required if a tax rate of has to be paid to the state. It consists of a part that is tax deductible (depreciation of the plant investment) and a second part of the operational costs that is not deductible. By dividing by $(1-\mathrm{T})$, the before-tax revenue is calculated.

$$
\mathrm{TLCC}=\frac{\mathrm{I}-\left(\mathrm{T} \times \mathrm{PV}_{\mathrm{DEP}}\right)+(1-\mathrm{T}) \mathrm{PV} \mathrm{O}_{\mathrm{OM}}}{1-\mathrm{T}}
$$

where I denotes the investment costs, $\mathrm{T}$ the tax rate, $\mathrm{PV} \mathrm{DEP}_{\mathrm{DEP}}$ the present value of the series of occurring depreciation, and $\mathrm{PV}_{\mathrm{O} \& \mathrm{M}}$ the present value of operation and maintenance costs (see also Equation (2)). The present value of recurring costs $C$ over a time period is found with Equation (2). In case of constant annual payments, the Equation can be simplified 
using the annuity factor $\mathrm{A}=\mathrm{i}\left(1-(1+\mathrm{i})^{-\mathrm{n}}\right)^{-1}$, where i denotes the interest rate and $\mathrm{n}$ the lifetime of the plant.

$$
\mathrm{PV}_{\mathrm{x}=\{\mathrm{DEP}, \mathrm{O \& M}\}}=\sum_{\mathrm{j}=1}^{\mathrm{n}} \frac{\mathrm{C}_{\mathrm{j}}}{(1+\mathrm{i})^{\mathrm{j}}}=\mathrm{C}_{\mathrm{j}} \times \mathrm{A}
$$

The production costs, or levelized costs per kilogram of hydrogen ( $\mathrm{LCOH})$, are then determined by dividing the TLCC by the annuity factor times the annual production rate $\mathrm{Q}\left[\mathrm{kg} \mathrm{H}_{2}\right.$ per year]: $\mathrm{LCOH}=\frac{\mathrm{TLCC}}{\mathrm{O} \times \mathrm{A}}$ [46]. The $\mathrm{LCOH}$ are then the total costs accumulated over the lifetime of the plant, discounted to their present value at the start of the project and annualized, and divided by the annual amount of produced hydrogen. It is further assumed that the project is supported by the government and that no taxes have to be paid. Equation (1) then is simplified to TLCC $=\mathrm{I}+\mathrm{PV}_{\mathrm{O} \& \mathrm{M}}$.

For the derivation of $\mathrm{LCOH}$, it is therefore required to determine the investment costs and operational costs of the plant. The energy and mass balance (Figure 1) is the basis for the cost estimates, and specific data from manufacturers and the literature are used. Furthermore, the lifetime of the plant and the interest rate have to be assumed, where the former is chosen to be 25 years and the latter is found through the financing of $60 \%$ through debt and $40 \%$ through equity [47]. As the technology does not exist today, the task of determining an interest rate is a rather difficult one. The methodology as described in [25] is followed here, which uses economy-wide proxy indicators (here, for the USA) to determine suitable estimates for the interest rates of debt and equity. Official statistics of the IMF [48] for bank prime lending rates are used to derive debt interest rates, where the debt interest rate is taken to be the bank lending rate. The equity interest rate, on the other hand, is defined to be the sum of government bond yields and equity risk premiums (ERP). Bond yields can be found in publicly accessible databases $[49,50]$ and the ERP is determined following [51], where country risk premiums are derived from mature market premiums that are increased by specific country risk premiums. With this method, the US debt interest is $4.1 \%$ and the equity interest rate is $8.2 \%$. The value used for inflation is taken to be the average of the years 2013-2017 to avoid short-term distorting effects [52].

\subsection{Life Cycle Assessment}

A life cycle assessment is performed on the identical baseline case of the plant located in the USA with a direct normal irradiation (DNI) of $2700 \mathrm{kWh} /\left(\mathrm{m}^{2} \mathrm{y}\right)$ at a distance of $250 \mathrm{~km}$ from the sea. The impact of GHGs is expressed in the metric of $\mathrm{CO}_{2}$-equivalents, and a system boundary of well-to-tank is chosen (including all upstream processes required for the production and transport of hydrogen to the customer but excluding its final use). If the hydrogen is combusted near the surface of the earth, little to no further climate impact is taken into account. However, if the hydrogen is combusted in an airplane, there may be a significant impact on the climate through the emission of water vapor in the higher atmosphere and non- $\mathrm{CO}_{2}$ effects such as the emission of $\mathrm{NO}_{\mathrm{x}}$. With non- $\mathrm{CO}_{2}$ effects still being the subject of ongoing research efforts, it appears difficult to determine their climate impact with a high degree of confidence. Nevertheless, published numbers can be taken from the literature to, e.g., compare the climate impact of a hydrogen-powered airplane to that of a conventionally-operated airplane. The analysis is limited here to the production of hydrogen, while its transport is discussed further below.

The impact analysis is performed based on the energy and mass balance shown in Figure 1, where one kilogram of hydrogen is chosen to be the functional unit of the analysis. The assessment is carried out using the software GaBi Professional [53] in combination with the ecoinvent database V3.5 [54]. The electrical energy required for the production of one kilogram of hydrogen is taken from the grid for seawater desalination and the pipeline transport of fresh water to the plant site, and from solar energy for on-site requirements. The environmental impacts of the latter are modelled using a CSP plant process. Transport of water (and eventually hydrogen) is modelled with a steel pipeline. The material 
demand of the thermochemical reactors is modelled using the $50-\mathrm{kW}_{\mathrm{th}}$-reactor size of the experimental campaign in the SUN-to-LIQUID project [55], resulting in $720 \mathrm{~kg}$ of steel, $615 \mathrm{~kg}$ of aluminum oxide, $301 \mathrm{~kg}$ of ceria, $5 \mathrm{~kg}$ of glass, and $45 \mathrm{~kg}$ of aluminum per unit.

\subsection{Geographical Potential}

The geographical potential is determined by firstly identifying the available areas in the USA for solar thermochemical hydrogen production. In a second step, the production potential and costs on the suitable areas are calculated as a function of DNI and distance to the sea (for supplying fresh water from the desalination plant). The software QGIS [QGIS Development Team (2017). QGIS Geographic Information System. Open Source Geospatial Foundation Project, http: / / qgis.osgeo.org, accessed on 1 March 2021] was used as a GIS-based tool for the net area calculations. Similar to the calculations performed in the MED CSP study [8] for the determination of suitable areas for CSP plants in the Mediterranean, the following areas were excluded: areas with existing ground structures, water bodies, shifting sands, slopes $\geq 5 \%$, and protected areas, as well as areas covered by forest, closed shrublands, woody savannas, wetlands, croplands, urban settlements, or snow/ice. Consequently, allowed land types are open shrubland, savannas, and barren or sparsely vegetated land, for which the restrictions listed above do not apply. More information on the methodology and the data sources used for the analysis can be found in [25].

\section{Results}

\subsection{Techno-Economic Assessment}

In the following section, the investment costs and the operational costs of the baseline case plant in the USA are described. A list of the investment costs is shown in Table 1 and their distribution in Figure 2. The O\&M costs are shown in Table 1 and Figure 3. Costs are converted from USD to EUR with an exchange rate of 1.13 representative of the year 2017 [56], unless otherwise indicated.

Table 1. Overview of investment and O\&M costs of the baseline case plant.

\begin{tabular}{ccc}
\hline Subsystem & Investment Costs $\left[\mathbf{1 0}^{\mathbf{6}} \boldsymbol{\epsilon}\right]$ & O\&M Costs $[\mathbf{1 0} \mathbf{6} \boldsymbol{\epsilon} / \mathbf{y}]$ \\
\hline Heliostats & 308 & 12.3 \\
Thermochemical reactors & 117 & 0.729 \\
H $_{2}$ storage & 98.1 & 2.94 \\
Solar tower & 63.5 & - \\
Water pipeline & 59.8 & 2.99 \\
Vacuum pumps & 52.6 & 1.58 \\
Buildings & 10.0 & - \\
Seawater desalination & 1.58 & 0.148 \\
Water pump and storage & 0.766 & 0.015 \\
Labor & - & 18.4 \\
Electricity & - & 2.51 \\
\hline Total & 710 & 41.6 \\
\hline
\end{tabular}




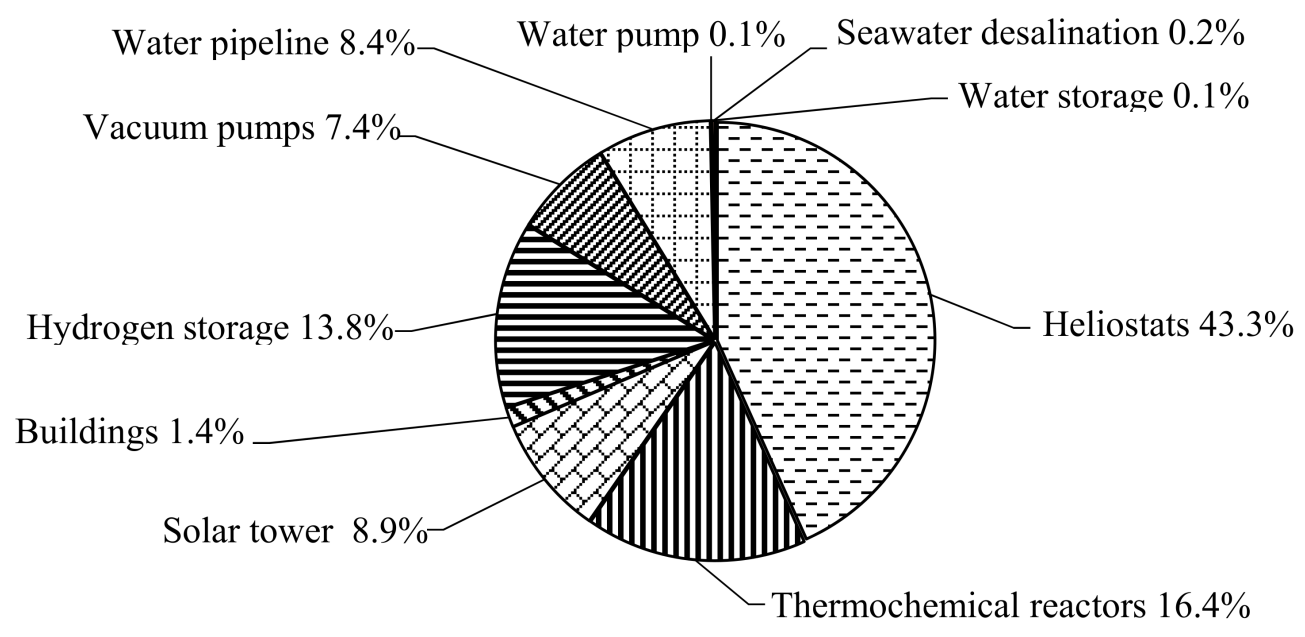

Figure 2. Distribution of investment costs of baseline case plant.

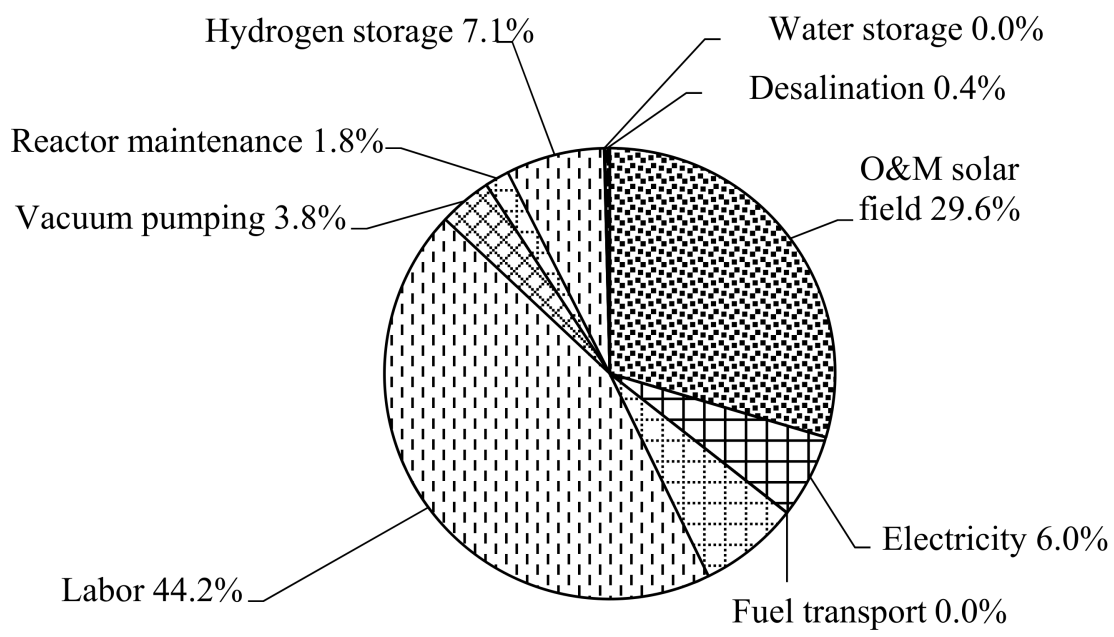

Figure 3. Distribution of O\&M costs of the baseline case plant.

\subsubsection{Investment Costs of the Baseline Case Plant}

The largest cost item is the heliostat field, which consists of mirrors at a specific cost of $50 \mathrm{EUR} / \mathrm{m}^{2}$, corresponding to the Sunshot target value for 2030 [57] for a baseload CSP plant delivering electricity at $0.05 \mathrm{USD} / \mathrm{kWh}_{\mathrm{el}}$. The tower costs are assumed to be $20 \mathrm{EUR}$ per $\mathrm{kW}_{\text {th }}$ [58] and the thermochemical reactors are assumed to cost $12 \mathrm{EUR}$ per $\mathrm{kW}_{\text {th }}$ based on an estimate in [25] that assumes mass production of $50 \mathrm{~kW}_{\text {th }}$-reactor units. For the plant with a production of $100 \mathrm{t} / \mathrm{d}$, approximately 45,000 of these reactor units would be required. Ceria is added with a unit cost of $5 \mathrm{EUR} / \mathrm{kg}$, which at the required amount of $16 \mathrm{kt}$ results in 80 million EUR, while the thermochemical reactors have a cost of 36.4 million EUR. Current market prices for ceria are lower at $1.5 \mathrm{EUR}_{2021} \mathrm{per} \mathrm{kg}$ and are expected to decline in the near future $[56,59]$. Ultimately, ceria may be replaced by another material with lower energy inputs per mol of hydrogen produced. Additionally, the limitations of ceria mining that could theoretically limit the deployment of the technology on a very large scale can be circumvented by alternative materials in the perovskite class that offer a very large range of possible material combinations. The unit cost of the water pipeline is $239 \mathrm{EUR} / \mathrm{m}$, using a pipeline diameter of $0.17 \mathrm{~m}$ and unit costs of $56 \mathrm{EUR} / \mathrm{m}$ for welded carbon steel pipes from [60]. This value is augmented by a factor of 4.24 according to the cost breakdown of product pipelines in the oil and gas industries in [61], which shows that the costs of pipeline materials account for $23.6 \%$ of the total costs of a pipeline. The investment costs for jet vacuum pumps are taken from [62] and are a function of reduction pressures with strongly increasing costs towards low pressures. At the chosen baseline reduction pressure 
of $1200 \mathrm{~Pa}$ and the required oxygen flow rate of $870 \mathrm{~mol} \mathrm{~s}^{-1}$ (assuming an operation of eight hours per day), the vacuum pumps cost 52.6 million EUR. Included in the final cost are factors of 0.2 for installation and 0.23 for additional costs, which are added to the bare component costs. Hydrogen is stored at a pressure of 16 bar on site as a buffer for further transport to the final customer. The cost for the hydrogen storage system is assumed to be 15 EUR per kWh [63].

\subsubsection{Operation and Maintenance Costs of the Baseline Case Plant}

Operation and maintenance of the heliostat field is taken into account with $2 \%$ of the initial investment cost per year, which is based on an estimate for central receiver systems [64]. Electricity generation is assumed to have unit costs of $0.04 \mathrm{EUR} / \mathrm{kWh}$ el both for solar electricity generated on site and for grid electricity. We therefore assume a cost reduction for both solar and grid electricity with respect to values achieved today. The maintenance of all other systems is assumed to be $3 \%$ of the respective investment costs per year, except for the thermochemical reactors, which are taken to require $2 \%$ per year plus the labor costs associated with the refurbishing of ceria (see below for more detailed assumptions). The largest O\&M cost item is due to labor costs, which are determined based on an estimate of the required workforce. Using published values for comparable CSP plants [65-69], it is assumed that the baseline case plant requires 5 managers, 30 engineers, 15 clerks, 100 technicians, and 229 workers. The number of workers is comprised of 84 workers for the replacement of ceria (whereas the material can be refurbished and reused in the reactors, and is not consumed), and 145 workers for the rest of the plant (solar concentration, gas handling and storage). It is assumed that the redox material ceria has to be replaced after 500 cycles, while 16 cycles can be performed on a single reactor per day [25]. The replacement is assumed to require $15 \mathrm{~min}$ per reactor. The labor associated with the plant construction is assumed to be included in the investment costs. For the determination of country-specific labor costs (here, the USA), the methodology used in [25] is used. Data from the International Labor Organisation (ILO) is gathered and the harmonized series of mean nominal monthly earnings is used. A distribution of respective occupations corresponding to the defined classes above is performed and the estimated work hours are multiplied with the specific salaries to determine the labor costs. For the USA, the labor costs are 18.4 million EUR. The second largest cost item is for the operation and maintenance of the heliostat field, which requires 12.3 million EUR per year.

\subsubsection{Production Costs}

Using the investment costs and the O\&M costs from above, the production costs are $2.43 \mathrm{EUR} / \mathrm{kg}$ in real 2017 currency. Taking into account an assumed inflation of $1.32 \%$ over the project lifetime of 25 years, the nominal value of the production costs is $2.79 \mathrm{EUR} / \mathrm{kg}$. An overview of the cost items is shown in Figure 4. The investment costs contribute $53 \%$ of the overall production costs, and the O\&M costs contribute $47 \%$. Building and maintaining the solar concentrator has the largest influence on the costs, followed by the labor costs, which are relatively high in the USA. Moving into a different country with lower labor rates but still an excellent solar resource, such as Chile, could further reduce the production costs of solar thermochemical hydrogen. 


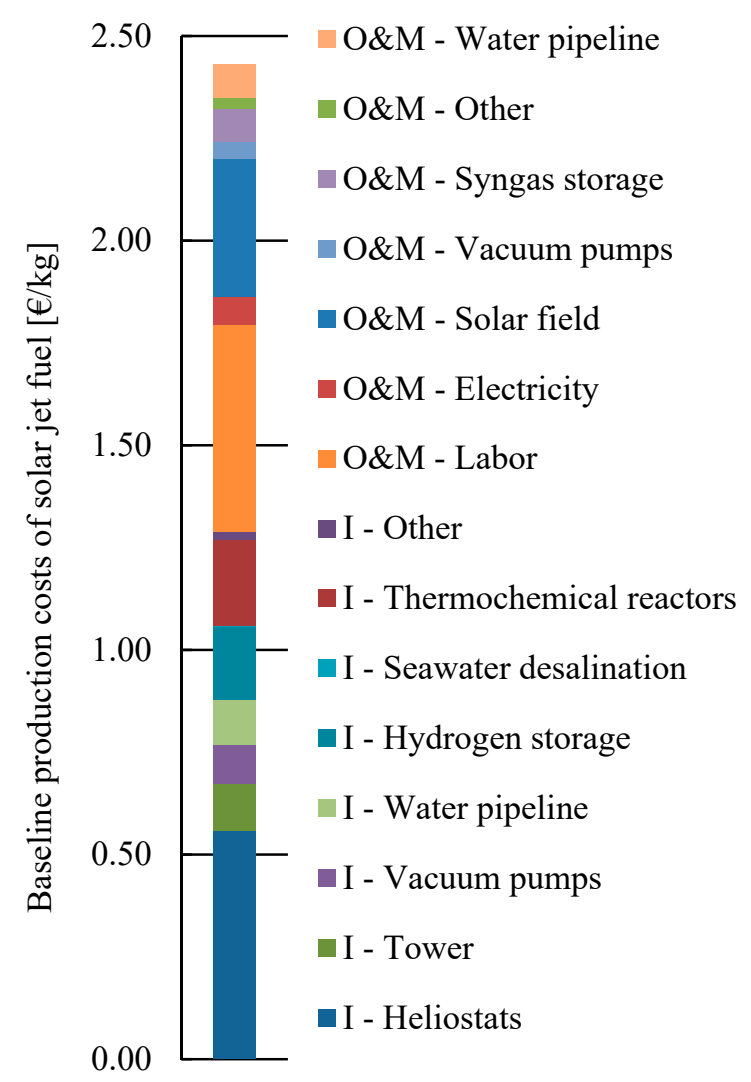

Figure 4. Production costs of solar thermochemical hydrogen for the baseline case plant design.

4.1.4. Sensitivity of Production Costs with Respect to Solar Radiation, Reactor Efficiency and Distance to the Sea

The production costs depend to a large degree on the size of the heliostat field, which is determined by the solar radiation (DNI) at the plant site and the reactor efficiency. At higher irradiation levels and constant output of the plant, a smaller heliostat field can provide the required amount of concentrated energy to the thermochemical reactors and thus lower the investment and O\&M costs. At a less favorable site, the heliostat field may need to be larger in order to deliver the specified power level, which will increase the production costs. The reactor efficiency therefore scales the heliostat field and the associated costs. As a second geographical variable, the distance to the sea has an impact on the production costs because it determines the length of the water pipeline.

It is assumed that a direct connection to the sea can be made by the pipeline, neglecting any possible altitude differences. The dependency of production costs on DNI, distance from the sea, and reactor efficiency is shown in Figure 4, whereas all other parameters are left constant.

From a solar radiation of $2000 \mathrm{kWh} /\left(\mathrm{m}^{2} \mathrm{y}\right)$, as found in the South of Spain, to the best locations with $3500 \mathrm{kWh} /\left(\mathrm{m}^{2} \mathrm{y}\right)$, such as in the Andes, the production costs drop by about $20 \%$. The influence of the reactor efficiency is also very strong, which causes production costs to drop by over half when going from a value of $5 \%$ to $20 \%$. The distance to the sea finally causes costs to increase by $17 \%$ when moving from the seaside to a location at a distance of $500 \mathrm{~km}$.

\subsection{Life Cycle Emissions}

The GHG emissions of solar thermochemical hydrogen production in the baseline case, excluding transport, are $1.44 \mathrm{~kg} \mathrm{CO}$-eq. per $\mathrm{kg} \mathrm{H}_{2}$ (shown in Table 2). The largest contribution to the emissions is found to be the solar concentration infrastructure consisting mainly of steel, concrete, and glass, followed by the thermochemical reactors made of steel, aluminum, aluminum oxide, and also glass. The generation of CSP electricity and seawater 
desalination has a contribution of about $0.1 \mathrm{~kg} \mathrm{CO}_{2}$ eq. $\mathrm{kg}^{-1} \mathrm{H}_{2}$ or about $8 \%$ of the total emissions. The production of one kilogram of hydrogen with the solar thermochemical fuel pathway therefore causes emissions that are about $90 \%$ less than the conventional pathway of steam methane reforming (SMR) [70].

Table 2. GHG emissions of $1 \mathrm{~kg}$ gaseous $\mathrm{H}_{2}$ at standard conditions in the baseline case. Emissions of ceria mining are included in "other".

\begin{tabular}{cc}
\hline GHG Emissions of Subsystem & {$\left[\mathbf{k g}_{\mathrm{CO} \text {-eq. }} \mathbf{~ k g}^{-\mathbf{1}} \mathbf{H}_{\mathbf{2}}\right]$} \\
\hline Solar concentration & 0.85 \\
Thermochemical conversion & 0.25 \\
Electricity & 0.12 \\
Seawater desalination & 0.11 \\
Other & 0.06 \\
Pipeline transport water & 0.05 \\
\hline Total GHG emissions & $\mathbf{1 . 4 4}$ \\
\hline GHG emissions of $\mathrm{H}_{2}$ from NG reforming & $12.95^{\mathrm{a}}$ \\
\hline GHG emissions relative to conventional fuel & $11^{\circ}$ \\
\hline a Ref. [70].
\end{tabular}

\subsection{Geographical Potential}

A map of the suitable areas with a color code for the excluded areas in the USA is shown in [26] (Figure 5 therein). The production costs on suitable areas are shown in Figure 6 below. The range of production costs is 2.1-3.2 EUR/ $\mathrm{kg}$ (with a few values at higher costs), with the best locations in the Southwest close to the sea, which prevents elevated costs for water pipeline transport to the plant. The largest production costs are found in locations far from the sea with a low level of solar irradiation. As the solar resource is highest in the Southwest, where also the largest available areas are found, the production potential is highest in California, Nevada, Arizona, New Mexico, Utah, and Texas.

In Figure 7, the cost-supply relationship of solar thermochemical hydrogen production in the USA is shown. Due to the large areas with a favorable solar resource and moderate distance to the sea, most of the production achieves costs between 2.1 and $3.2 \mathrm{EUR} / \mathrm{kg}$, which is a very competitive value for renewable hydrogen production. On all available areas combined, a total of $8.4 \times 10^{11} \mathrm{~kg}$ per year can be produced, which corresponds to about twelve times the current global hydrogen production [5] and over 80 times the annual US production.
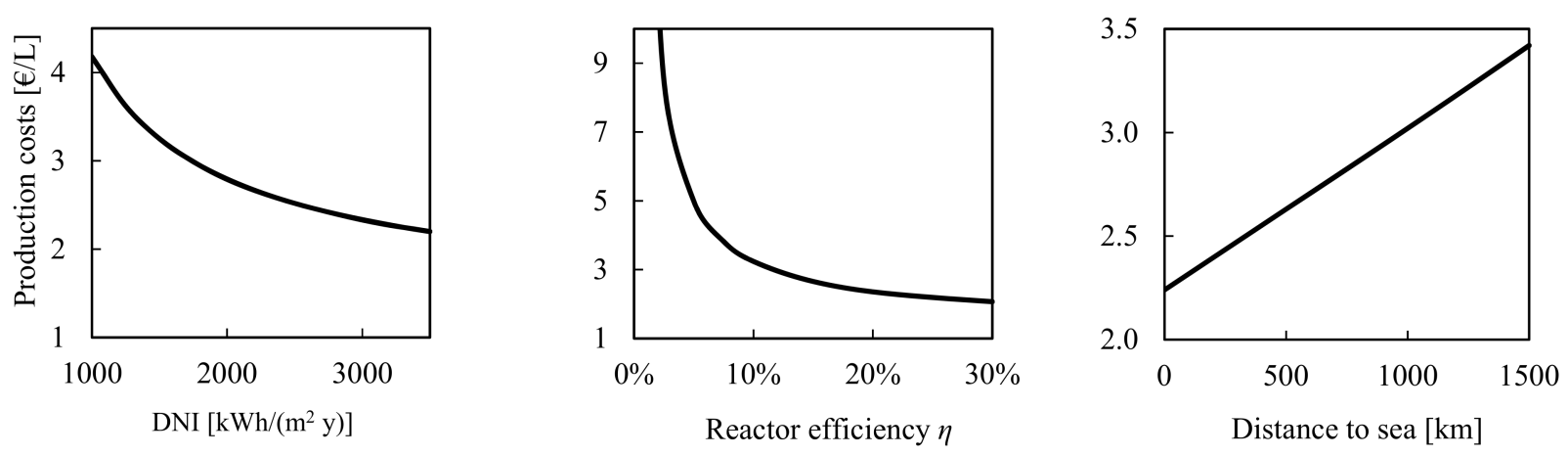

Figure 5. Production costs as a function of solar irradiation (DNI, left), reactor efficiency ( $\eta$, center), and distance to sea (right), whereas the latter determines the length of the water pipeline. 


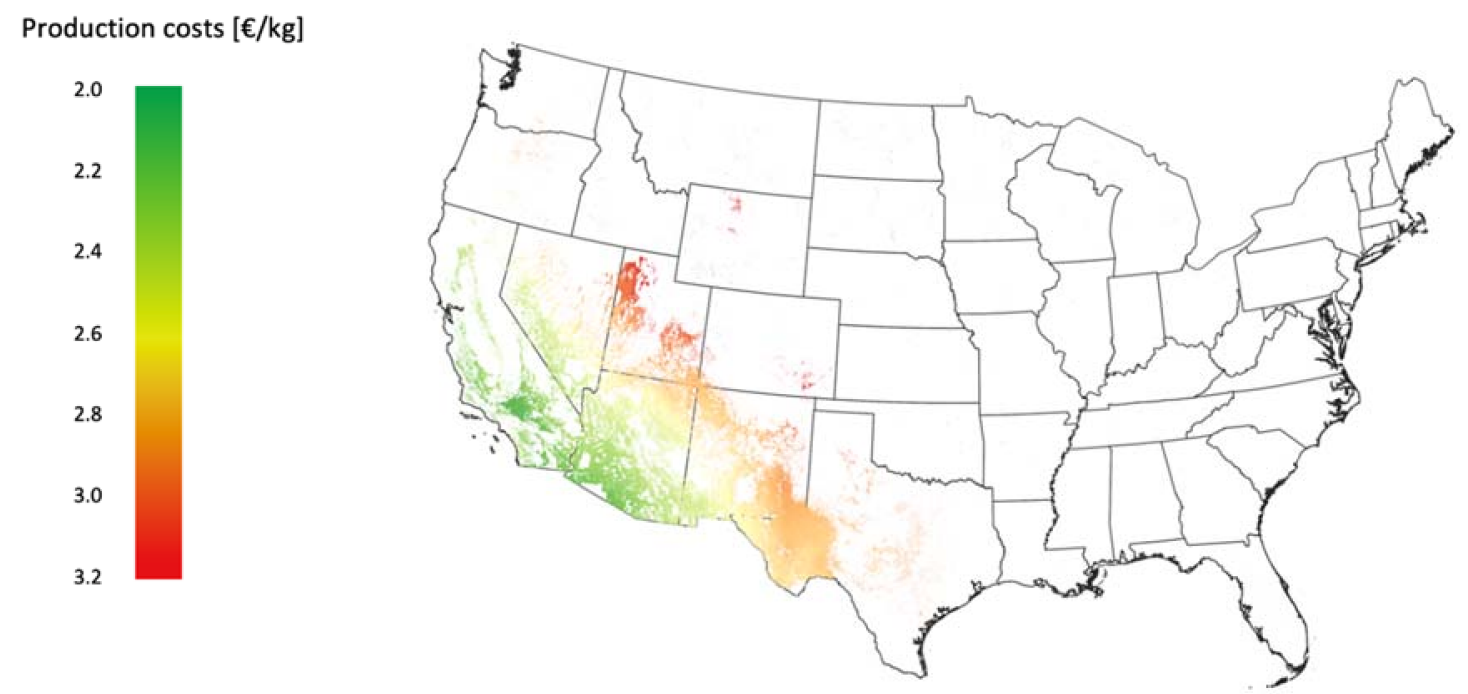

Figure 6. Production costs of solar thermochemical hydrogen in the USA. Only suitable areas are shown after the exclusion of areas due to sustainability criteria following the methodology in [26].

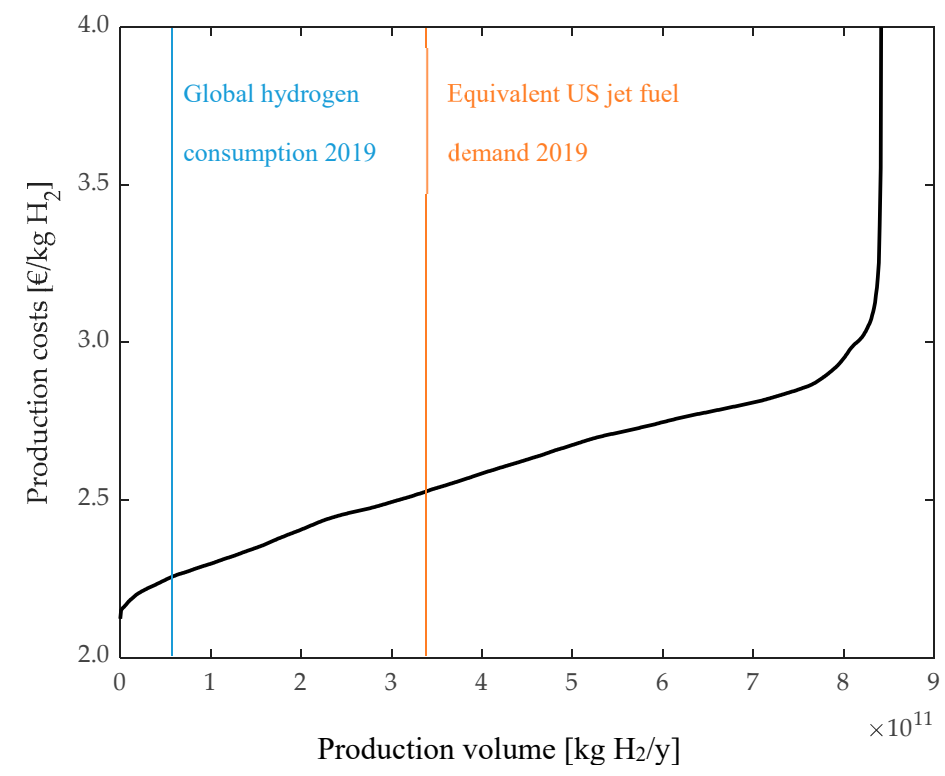

Figure 7. Cost-supply curve for solar thermochemical hydrogen production in the USA.

\section{Discussion}

The solar thermochemical pathway could supply hydrogen at competitive costs and low emissions in the future, assuming that technical advances towards higher efficiencies and lower costs of the solar concentration and $\mathrm{CO}_{2}$ capture infrastructure are made. At an estimated production cost of $<2.50 \mathrm{EUR} / \mathrm{kg}$ and a global warming potential of $1.4 \mathrm{~kg}$ $\mathrm{CO}_{2}$-eq. $/ \mathrm{kg} \mathrm{H}_{2}$, the costs are about double that of conventional $\mathrm{H}_{2}$ from $\mathrm{SMR}$, at $90 \%$ reduced emissions (excluding transport of $\mathrm{H}_{2}$ ). This is a significant improvement of the environmental performance at competitive costs. In principle, even higher efficiencies and thus lower costs are achievable, considering also that better locations with higher solar irradiation and/or lower labor costs exist such as Chile, Australia, and Namibia. For comparison, for the production from electrolysis with renewable electricity, costs of $<2 \mathrm{EUR} / \mathrm{kg}$ for $0.018 \mathrm{EUR} / \mathrm{kWh}$ of electricity and 220-440 EUR $/ \mathrm{kg}$ for the electrolyzer are estimated [12], which could be reached in the future.

Hydrogen is used for different purposes, such as its use as a reacting agent in the chemical industry for the production of fertilizers, pharmaceuticals, and plastics [71]. Its 
production volume in 2019 was $120 \mathrm{Mt}$ (14 EJ) per year and this is expected to grow to $160 \mathrm{Mt}$ (19 EJ) in 2050 [72] according to IRENA, or even to $670 \mathrm{Mt}$ (80 EJ) according to the Hydrogen Council [73]. Significant demand can also be seen for green steel production and on a potentially very large scale for transportation in the hard-to-decarbonize sectors such as aviation, shipping, and heavy-duty trucking. Depending on the size of the hydrogen market, not all of the demand will be covered by local production, but it is a credible scenario that large volumes of hydrogen will be produced at locations where cheap and reliable renewable energy is available. This, however, requires the large-scale transport of hydrogen from the production plant to the final consumer. The cost of the long-distance shipping of hydrogen has been estimated in the literature to be in the range of $13 \mathrm{EUR} / \mathrm{kg}$ today (including liquefaction) but to decline to $1.5 \mathrm{EUR} / \mathrm{kg}(0.5 \mathrm{EUR} / \mathrm{kg}$ excluding liquefaction) by 2030, given that a large infrastructure can be put in place, leveraging economies of scale [12]. In [19] $1.56 \mathrm{EUR} / \mathrm{kg}$ are derived for the pipeline transport over $100 \mathrm{~km}$ in a transmission pipeline and further distribution in 122 2.4-km segments. Pipeline transport over $250 \mathrm{~km}$ at a daily flow rate of $50 \mathrm{t}$ is indicated to cost $<2 \mathrm{EUR} / \mathrm{kg}$ in [21]. Yang and Ogden develop a transport model that gives a cost of $\sim 1 \mathrm{EUR} / \mathrm{kg}$ for transport via pipeline over $500 \mathrm{~km}$ at a flow rate of $100 \mathrm{t} / \mathrm{d}$ [74]. At a lower flow rate of $50 \mathrm{t} / \mathrm{d}$ and a distance of $100 \mathrm{~km}$, costs are below $0.5 \mathrm{EUR} / \mathrm{kg}$. For liquid trucking of $50 \mathrm{t} / \mathrm{d}$ over a distance of $500 \mathrm{~km}$, the model gives a cost of $1.1 \mathrm{EUR} / \mathrm{kg}$. The cost of trucking liquid $\mathrm{H}_{2}$ over a round-trip distance of $80 \mathrm{~km}$ is found to be $<0.1 \mathrm{EUR}_{2008} / \mathrm{kg}$ in [20]. For liquefaction, costs of about 1-2 USD/kg are estimated based on a study of liquefier investment costs in [75].

The GWP of $\mathrm{H}_{2}$ transport in pipelines is estimated at $0.3 \mathrm{~kg} \mathrm{CO}_{2}$-eq. $/ \mathrm{kg} \mathrm{H}_{2}$ in [19] for transport over transmission and distribution pipelines. For pipeline transport over $100 \mathrm{~km}$, $0.16 \mathrm{~kg} \mathrm{CO}$-eq. $/ \mathrm{kg} \mathrm{H}_{2}$ are estimated in [17] using renewable electricity for compression. The climate impacts of $\mathrm{H}_{2}$ transport depend on the source of electricity used, where renewable electricity can give a very low impact while the use of grid electricity, partly based on fossil energy in most countries, can significantly deteriorate the result.

Retail prices of $\mathrm{H}_{2}$ on a small scale of refilling cars are still very high, at an average of $>13.5 \mathrm{EUR} / \mathrm{kg}$ in California [76], where the largest part of the cost is due to the logistics of $\mathrm{H}_{2}$ transport, considering the production cost from steam methane reforming of $<1.3 \mathrm{EUR} / \mathrm{kg}$ [14], the by far largest source of $\mathrm{H}_{2}$ today. Of course, production from renewable energy and large-scale logistics will show a different picture if implemented in the future for a hydrogen economy. Considering the findings in the literature, an implementation to avoid excessive costs and GHG emissions for a large-scale $\mathrm{H}_{2}$ production and distribution network seems feasible, which nevertheless will require large investments into the infrastructure.

\section{Conclusions}

If technological advances are made and economies of scale for the production of the components can be used, hydrogen could be produced in the US at costs of approximately 2.1-3.2 EUR $/ \mathrm{kg}$ (2.4-3.6 USD $/ \mathrm{kg}$ ) with the solar thermochemical fuel pathway. While this would still be about double the price of $\mathrm{H}_{2}$ from steam methane reforming today, the most common pathway, the associated GHG emissions would be lower by about $90 \%$. The solar concentrator is the largest contributor to the GWP and production costs. For the latter, labor costs represent another important factor considering the United States, the location of interest, is a high-income country. The economic and environmental performance could be further improved by moving to locations with higher solar irradiation and lower labor costs (outside of the US). This and earlier work has shown that solar-thermochemical fuels show a strong sensitivity to the energy conversion efficiency and cost of capital $[24,25]$. As a consequence, commercialization is promoted by the low cost of capital, which suggests that de-risking such investments with policy measures or strategic partnerships (off-take agreements, etc.) is an important success factor for this technology as well.

A geographical potential analysis shows that $8.4 \times 10^{11} \mathrm{~kg}$ per year can be produced on all theoretically available areas in the US, which corresponds to about twelve times the 
current global hydrogen production and over 80 times the annual US production. Other uses or not using these areas at all will decrease the technical potential. Nevertheless, this large potential demonstrates that only a share of these areas would be required to cover even large hydrogen demands.

Finally, the current literature reveals that, given a large-scale implementation, hydrogen transport costs and associated emissions may not be prohibitive in the future. However, this requires large investments into the establishment of production and transport capacities to enable economies of scale. A viable option for initial scale-up of the solar thermochemical technology might be the introduction into existing (fossil) reforming and conversion plants, which would reduce the initial investment costs by making use of established technology at large scales and would in turn reduce the emissions of the fossil plants. Further research is planned to be carried out regarding the quantification of hydrogen transport costs and emissions in a dedicated model.

Author Contributions: Conceptualization, C.F.; methodology, C.F.; writing—original draft preparation, C.F.; writing - review and editing, C.F., A.S.; visualization, A.S., C.F. Both authors have read and agreed to the published version of the manuscript.

Funding: This research received no external funding.

Conflicts of Interest: The authors declare no conflict of interest.

\section{References}

1. UNFCCC. Adoption of the Paris Agreement; UNFCCC: Geneva, Switzerland, 2015.

2. European Commission. A Clean Planet for All. A European Long-Term Strategic Vision for a Prosperous, Modern, Competitive and Climate Neutral Economy; European Commission: Brussels, Belgium, 2018.

3. Ministry of Economy, Trade and Industry, Basic Hydrogen Strategy Determined. 2017. Available online: https:/ /www.meti.go. jp/english/press/2017/1226_003.html (accessed on 11 July 2021).

4. German Government. The National Hydrogen Strategy Germany. 2020. Available online: https://www.cleanenergywire.org/ factsheets/germanys-national-hydrogen-strategy (accessed on 11 July 2021).

5. IEA. The Future of Hydrogen; IEA: Paris, France, 2019.

6. Shell, and Wuppertal Institute. Shell Hydrogen Study: Energy of the Future? 2016. Available online: https://epub.wupperinst. org/frontdoor/deliver/index/docId/6786/file/6786_Hydrogen_Study.pdf (accessed on 11 July 2021).

7. Fletcher, E.A.; Moen, R.L. Hydrogen- and Oxygen from Water. Science 1977, 197, 1050-1056. [CrossRef]

8. Scheffe, J.R.; Steinfeld, A. Thermodynamic Analysis of Cerium-Based Oxides for Solar Thermochemical Fuel Production. Energy Fuels 2012, 26, 1928-1936. [CrossRef]

9. Hinkley, J.; Hayward, J.; Mcnaughton, R.; Gillespie, R.; Watt, M.; Lovegrove, K. Cost Assessment of Hydrogen Production from PV and Electrolysis, CSIRO ENERGY, Project A-3018. 2016. Available online: https://arena.gov.au/assets/2016/05/Assessmentof-the-cost-of-hydrogen-from-PV.pdf (accessed on 11 July 2021).

10. Eichman, J.; Koleva, M.; Guerra, O.J.; Mclaughlin, B.; Eichman, J.; Koleva, M.; Guerra, O.J. Optimizing an Integrated RenewableElectrolysis System Optimizing an Integrated Renewable-Electrolysis System. 2020. Available online: https:/ / www.nrel.gov/ docs/fy20osti/75635.pdf (accessed on 11 July 2021).

11. Wasserstoff, Hydrogen Study 2020-Umlaut. 2020. Available online: https://www.umlaut.com/de/stories/wasserstoff-studie2020 (accessed on 11 July 2021).

12. Hydrogen Council. Path to Hydrogen Competitiveness: A Cost Perspective. 2020. Available online: https:/ /hydrogencouncil. com/wp-content/uploads/2020/01/Path-to-Hydrogen-Competitiveness_Full-Study-1.pdf (accessed on 11 July 2021).

13. Chapman, A.J.; Fraser, T.; Itaoka, K. Hydrogen Import Pathway Comparison Framework Incorporating Cost and Social Preference: Case Studies from Australia to Japan. Int. J. Energy Res. 2017, 41, 2374-2391. [CrossRef]

14. Parkinson, B.; Balcombe, P.; Speirs, J.F.; Hawkes, A.D.; Hellgardt, K. Levelized Cost of $\mathrm{CO}_{2}$ Mitigation from Hydrogen Production Routes. Energy Environ. Sci. 2019, 12, 19-40. [CrossRef]

15. Shaner, M.R.; Atwater, H.A.; Lewis, N.S.; McFarland, E.W. A Comparative Technoeconomic Analysis of Renewable Hydrogen Production Using Solar Energy. Energy Environ. Sci. 2016, 9, 2354-2371. [CrossRef]

16. Stokes, J.; Horvath, A. Life Cycle Energy Assessment of Alternative Water Supply Systems (9 pp). Int. J. Life Cycle Assess. 2005, 11, 335-343. [CrossRef]

17. Wulf, C.; Reuß, M.; Grube, T.; Zapp, P.; Robinius, M.; Hake, J.F.; Stolten, D. Life Cycle Assessment of Hydrogen Transport and Distribution Options. J. Clean. Prod. 2018, 199, 431-443. [CrossRef]

18. Bareiß, K.; de la Rua, C.; Möckl, M.; Hamacher, T. Life Cycle Assessment of Hydrogen from Proton Exchange Membrane Water Electrolysis in Future Energy Systems. Appl. Energy 2019, 237, 862-872. [CrossRef] 
19. Ramsden, T.; Ruth, M.; Diakov, V.; Laffen, M.; Timbario, T.A. Hydrogen Pathways: Updated Cost, Well-to-Wheels Energy Use, and Emissions for the Current Technology Status of Ten Hydrogen Production, Delivery, and Distribution Scenarios; NREL/TP-6A10-60528. 2013. Available online: https://www.nrel.gov/docs/fy14osti/60528.pdf (accessed on 11 July 2021).

20. Nexant. Final Report-Hydrogen Delivery Infrastructure Options Analysis Models; Office of Energy Efficiency \& Renewable Energy: Washington, DC, USA, 2008.

21. Reuß, M.; Grube, T.; Robinius, M.; Preuster, P.; Wasserscheid, P.; Stolten, D. Seasonal Storage and Alternative Carriers: A Flexible Hydrogen Supply Chain Model. Appl. Energy 2017, 200, 290-302. [CrossRef]

22. Graf, D.; Monnerie, N.; Roeb, M.; Schmitz, M.; Sattler, C. Economic Comparison of Solar Hydrogen Generation by Means of Thermochemical Cycles and Electrolysis. Int. J. Hydrogen Energy 2008, 33, 4511-4519. [CrossRef]

23. Nicodemus, J.H. Technological Learning and the Future of Solar H2: A Component Learning Comparison of Solar Thermochemical Cycles and Electrolysis with Solar PV. Energy Policy 2018, 120, 100-109. [CrossRef]

24. Falter, C.; Batteiger, V.; Sizmann, A. Climate Impact and Economic Feasibility of Solar Thermochemical Jet Fuel Production. Environ. Sci. Technol. 2016, 50, 470-477. [CrossRef]

25. Falter, C.; Valente, A.; Habersetzer, A.; Iribarren, D.; Dufour, J. An Integrated Techno-Economic, Environmental and Social Assessment of the Solar Thermochemical Fuel Pathway. Sustain. Energy Fuels 2020, 4, 3992-4002. [CrossRef]

26. Falter, C.; Scharfenberg, N.; Habersetzer, A. Geographical Potential of Solar Thermochemical Jet Fuel Production. Energies 2020, 13, 802. [CrossRef]

27. Chueh, W.C.; Falter, C.; Abbott, M.; Scipio, D.; Furler, P.; Haile, S.M.; Steinfeld, A. High-Flux Solar-Driven Thermochemical Dissociation of CO2 and $\mathrm{H} 2 \mathrm{O}$ Using Nonstoichiometric Ceria. Science 2010, 330, 1797-1801. [CrossRef]

28. Furler, P.; Scheffe, J.; Gorbar, M.; Moes, L.; Vogt, U.; Steinfeld, A. Solar Thermochemical $\mathrm{CO}_{2}$ Splitting Utilizing a Reticulated Porous Ceria Redox System. Energy Fuels 2012, 26, 7051-7059. [CrossRef]

29. Marxer, D.; Furler, P.; Takacs, M.; Steinfeld, A. Solar Thermochemical Splitting of $\mathrm{CO}_{2}$ into Separate Streams of $\mathrm{CO}$ and $\mathrm{O}_{2}$ with High Selectivity, Stability, Conversion, and Efficiency. Energy Environ. Sci. 2017, 10, 1142-1149. [CrossRef]

30. Stechel, E.B.; Miller, J.E. Re-Energizing $\mathrm{CO}_{2}$ to Fuels with the Sun: Issues of Efficiency, Scale, and Economics. J. CO 2 Util. 2013, 1 , 28-36. [CrossRef]

31. Hoes, M.; Ackermann, S.; Theiler, D.; Furler, P.; Steinfeld, A. Additive-Manufactured Ordered Porous Structures Made of Ceria for Concentrating Solar Applications. Energy Technol. 2019, 1900484, 1-8. [CrossRef]

32. Scheffe, J.R.; Steinfeld, A. Oxygen Exchange Materials for Solar Thermochemical Splitting of $\mathrm{H}_{2} \mathrm{O}$ and $\mathrm{CO}_{2}$ : A Review. Mater. Today 2014, 17, 341-348. [CrossRef]

33. Geissbühler, L. Thermocline Thermal Energy Storage: Advances and Applications to CSP, Compressed Air Energy Storage, and Solar Fuels. Ph.D. Thesis, ETH Zürich, Zürich, Switzerland, 2019.

34. Chueh, W.C.; Haile, S.M. A Thermochemical Study of Ceria: Exploiting an Old Material for New Modes of Energy Conversion and $\mathrm{CO}_{2}$ Mitigation. Philos. Trans. A Math. Phys. Eng. Sci. 2010, 368, 3269-3294. [CrossRef]

35. Ezbiri, M.; Allen, K.M.; Gàlvez, M.E.; Michalsky, R.; Steinfeld, A. Design Principles of Perovskites for Thermochemical Oxygen Separation. ChemSusChem 2015, 8, 1966-1971. [CrossRef]

36. Demont, A.; Abanades, S.; Beche, E. Investigation of Perovskite Structures as Oxygen-Exchange Redox Materials for Hydrogen Production from Thermochemical Two-Step Water-Splitting Cycles. J. Phys. Chem. C 2014, 118, 12682-12692. [CrossRef]

37. McDaniel, A.H.; Miller, E.C.; Arifin, D.; Ambrosini, A.; Coker, E.N.; O’Hayre, R.; Chueh, W.C.; Tong, J. Sr- and Mn-Doped $\mathrm{LaAlO}_{3}-\delta$ for Solar Thermochemical $\mathrm{H}_{2}$ and CO Production. Energy Environ. Sci. 2013, 6, 2424. [CrossRef]

38. Ezbiri, M.; Becattini, V.; Hoes, M.; Michalsky, R.; Steinfeld, A. High Redox Capacity of Al-Doped $\mathrm{La}_{1-\mathrm{x}} \mathrm{Sr}_{\mathrm{x}} \mathrm{MnO}_{3-\delta} \mathrm{Perovskites}$ for Splitting $\mathrm{CO}_{2}$ and $\mathrm{H}_{2} \mathrm{O}$ at Mn-Enriched Surfaces. ChemSusChem 2017, 10, 1517-1525. [CrossRef]

39. Scheffe, J.R.; Weibel, D.; Steinfeld, A. Lanthanum-Strontium-Manganese Perovskites as Redox Materials for Solar Thermochemical Splitting of $\mathrm{H}_{2} \mathrm{O}$ and $\mathrm{CO}_{2}$. Energy Fuels 2013, 27, 4250-4257. [CrossRef]

40. Elimelech, M.; Phillip, W.A. The Future of Seawater Desalination: Energy, Technology, and the Environment. Science 2011, 333, 712-717. [CrossRef]

41. Caldera, U.; Bogdanov, D.; Breyer, C. Local Cost of Seawater RO Desalination Based on Solar PV and Wind Energy: A Global Estimate. Desalination 2016, 385, 207-216. [CrossRef]

42. Whitaker, M.B.; Heath, G.A.; Burkhardt, J.J.; Turchi, C.S. Life Cycle Assessment of a Power Tower Concentrating Solar Plant and the Impacts of Key Design Alternatives. Environ. Sci. Technol. 2013, 47, 5896-5903. [CrossRef]

43. Sargent\&Lundy. Assessment of Parabolic Trough and Power Tower Solar Technology; SL-5641; Sargent\&Lundy: Chicago, IL, USA, 2003.

44. LAZARD. Levelized Cost of Energy and Levelized Cost of Storage. 2020. Available online: https://www.lazard.com/perspective/ levelized-cost-of-energy-and-levelized-cost-of-storage-2020/ (accessed on 1 March 2021).

45. IRENA. Renewable Energy Generation Costs in 2019; IRENA: Abu Dhabi, United Arab Emirates, 2020.

46. Short, W.; Packey, D.J.; Holt, T. A Manual for the Economic Evaluation of Energy Efficiency and Renewable Energy Technologies; NREL/TP-462-5173. 1995. Available online: https:/ /www.nrel.gov/docs/legosti/old/5173.pdf (accessed on 11 July 2021).

47. SunShot U.S. Department of Energy. SunShot Vision Study; National Renewable Energy Lab (NREL): Golden, CO, USA, 2012.

48. International Monetary Fund. Lending Rates, Percent per Annum. 2018. Available online: https://data.imf.org/regular.aspx? key=61545867 (accessed on 3 July 2019). 
49. Trading Economics. Government Bond Yields. 2018. Available online: https://tradingeconomics.com/bonds (accessed on 2 August 2019).

50. World Government Bonds. 10 Year Bond Yields. 2018. Available online: http://www.worldgovernmentbonds.com/ (accessed on 8 October 2019).

51. Damodoran, A. Estimated Country Risk Premiums. 2018. Available online: http://pages.stern.nyu.edu/ \{\}adamodar/ (accessed on 3 July 2019).

52. Worldbank. Inflation, Consumer Prices (Annual \%). Available online: https://datacatalog.worldbank.org/inflation-consumerprices-annual-0 (accessed on 25 February 2021).

53. Thinkstep, A.G. GaBi Software-System and Database for Life Cycle Engineering. Available online: https://www.researchgate net/figure/2-Software-for-LCA-The-thinkstep-GaBi-software-System-and-Database-for-Life-Cycle_fig4_331564116 (accessed on 25 February 2021).

54. Wernet, G.; Bauer, C.; Steubing, B.; Reinhard, J.; Moreno-Ruiz, E.; Weidema, B. The Ecoinvent Database Version 3 (Part I): Overview and Methodology. Int. J. Life Cycle Assess. 2016, 2, 1218-1230. [CrossRef]

55. Horizon 2020-Project SUN-to-LIQUID. Grant Agreement Number 654408. Available online: https://ec.europa.eu/inea/en/ horizon-2020/projects/h2020-energy/alternative-fuels/sun-to-liquid (accessed on 11 July 2021).

56. Macrotrends. Euro Dollar Exchange Rate (EUR USD)—Historical Chart. Available online: https://www.macrotrends.net/2548 / euro-dollar-exchange-rate-historical-chart (accessed on 25 February 2021).

57. U.S. DOE. The SunShot 2030 Goals. 2017. Available online: https://www.energy.gov/sites/prod/files/2020/09/f79/SunShot\% 202030\%20White\%20Paper.pdf (accessed on 11 July 2021).

58. Mancini, T.R.; Gary, J.A.; Kolb, G.J.; Ho, C.K. Power Tower Technology Roadmap and Cost Reduction Plan; OSTI.GOV: Oak Ridge, TN, USA, 2011.

59. Costs of Ceria. 2019. Available online: https://www.statista.com/statistics/450146/global-reo-cerium-oxide-price-forecast/ (accessed on 1 March 2021).

60. Peters, M.S.; Timmerhaus, K.D.; West, R.E. Plant Design and Economics for Chemical Engineers. 2003. Available online: http:/ / repository.um-palembang.ac.id/id/eprint/9024/1/Plant\%20Design\%20and\%20Economics\%20for $\% 20$ Chemical $\% 20$ Engineers \%20\%28\%20PDFDrive.com\%20\%29.pdf (accessed on 11 July 2021).

61. Smith, C.E. Crude Oil Pipeline Growth, Revenues Surge; Construction Costs Mount. Oil Gas J. 2014, 112, $114-125$.

62. Brendelberger, S.; von Storch, H.; Bulfin, B.; Sattler, C. Vacuum Pumping Options for Application in Solar Thermochemical Redox Cycles-Assessment of Mechanical-, Jet- and Thermochemical Pumping Systems. Sol. Energy 2017, 141, 91-102. [CrossRef]

63. James, B.D.; Houchins, C.; Huya-Kouadio, J.M.; Desantis, D.A. Final Report: Hydrogen Storage System Cost Analysis 2016. Available online: https:/ / www.osti.gov/servlets/purl/1343975 (accessed on 11 July 2021).

64. Fichtner. Assessment of Technology Options for Development of Concentrating Solar Power in South Africa. Presentation. 2010. Available online: https://www.climateinvestmentfunds.org/sites/cif_enc/files/Presentation\%20-\%20WB\%20(Eskom) \%20Project\%20-\%202010_12_07\%20.pdf (accessed on 11 July 2021).

65. IRENA; Wallasch, A.-K.; Lüers, S.; Vidican, G.; Breitschopf, B.; Richter, A.; Kuntze, J.-C.; Noll, J. The Socio-Economic Benefits of Solar and Wind Energy; IRENA: Abu Dhabi, United Arab Emirates, 2014.

66. Sooriyaarachchi, T.M.; Tsai, I.T.; El Khatib, S.; Farid, A.M.; Mezher, T. Job Creation Potentials and Skill Requirements in, PV, CSP, Wind, Water-to-Energy and Energy Efficiency Value Chains. Renew. Sustain. Energy Rev. 2015, 52, 653-668. [CrossRef]

67. IRENA. IRENA Worling Paper Renewable Energy Jobs: Status, Prospects \& Policies. 2011. Available online: https: / / www.irena.org/-/media/Files/IRENA/Agency/Publication/2012/Renewable_Energy_Jobs_abstract.pdf?la=en\&hash=11 362A41C4805408223A4556FDA29E0235C7264C (accessed on 11 July 2021).

68. Applied Analysis. Large-Scale Solar Industry; Economic and Fiscal Impact Analysis: Las Vegas, NV, USA, 2009.

69. Gazzo, A.; Gousseland, P.; Verdier, J.; Kost, C.; Morin, G.; Engelken, M.; Schrof, J.; Nitz, P.; Selt, J.; Platzer, W.; et al. Middle East and North Africa Region Assessment of the Local Manufacturing Potential for Concentrated Solar Power (CSP) Projects; The World Bank: Washington, DC, USA, 2011.

70. Valente, A.; Iribarren, D.; Dufour, J. Harmonised Life-Cycle Global Warming Impact of Renewable Hydrogen. J. Clean. Prod. 2017, 149, 762-772. [CrossRef]

71. Royal Society of Chemistry. Hydrogen. Available online: https://www.rsc.org/periodic-table/element/1/hydrogen (accessed on 1 October 2020).

72. IRENA. Hydrogen: A Renewable Energy Perspective; IRENA: Abu Dhabi, United Arab Emirates, 2019.

73. Hydrogen Council. Hydrogen Scaling up. 2017. Available online: https://hydrogencouncil.com/en/study-hydrogen-scalingup/ (accessed on 11 July 2021).

74. Yang, C.; Ogden, J. Determining the Lowest-Cost Hydrogen Delivery Mode. Int. J. Hydrogen Energy 2007, 32, 268-286. [CrossRef]

75. Connelly, E.; Penev, M.; Elgowainy, A.; Hunter, C. Current Status of Hydrogen Liquefaction Costs. 2019. Available online: https:/ / www.hydrogen.energy.gov/pdfs/19001_hydrogen_liquefaction_costs.pdf (accessed on 11 July 2021).

76. Baronas, J.; Achtelik, G. Joint Agency Staff Report on Assembly Bill 8: Assessment of Time and Cost Needed to Attain 100 Hydrogen Refueling Stations in California; California Energy Commission: Sacramento, CA, USA, 2015. 